\title{
Making Sense of Researcher Positionality in Foundational Literacy Studies Research
}

\author{
Amy J. Wan - Queens College, City University of New York

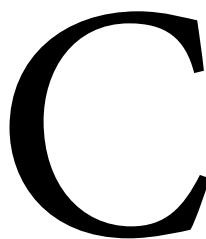 \\ armen Kynard, in this journal's first issue, describes how when we as a field \\ have studied literacy, language, and discourse, "we have done so mostly from \\ the spaces of methodological considerations (either borrowing from history or \\ from anthropology/ethnography); we have not done so from the perspectives \\ of interrogating deep political and ideological shifts that have left structured
} inequalities and violence firmly in place, especially in reference to, but not solely based on, race" ("Literacy/Literacies" 64).

Kynard pays particular attention to the impact of race, while also giving recognition to the "perspectives of interrogating deep political and ideological shifts that have left structured inequalities and violence firmly in place" (64). The implication of what Kynard is arguing is that our methodological considerations cannot be separated from our political contexts, that our researcher positionalities are part of the social contexts in which literacy, language, and discourse are being studied. This attention to researcher positionality has often been implicit, part of what Brian Street might refer to as the larger social contexts of literacy.

Given the recognition of the importance of positionality and its influence on methodology in education and ethnography (Gómez-Barris; Harrison; Kovach; Mignolo; Mutua and Swadener; Weis and Fine; Patel; Sefa Dei; Watson and Huntington; Wilson) and in rhetoric and composition (Agboka; Cedillo; García and Baca; Inoue; Kynard; Martinez; Powell), what might literacy studies now make of a foundational scholar like Brian Street, someone whose groundbreaking work helped expand notions of literacy beyond white Western norms but who did so as a white British researcher working in Iran in the 1970s? How do we move with Street in our thinking as we continue to interrogate and find ways to do research in ways that reduce harm to the people who are being studied? Street's scholarly contributions have been foundational in the understanding of how literacy works within social contexts, but how does one acknowledge "foundational" without dominance and erasure? How can research be more than harm reduction and make space for answerability rather than ownership, as Lisa (Leigh) Patel argues? What I attempt to do here is understand the social contexts of the research itself, to explore these critiques of researcher positionality with Street in mind, while also thinking forward to how his body of work can continue to be used alongside antiracist and decolonial approaches to literacy studies.

A key text in New Literacy Studies, Street's first most significant work, Literacy in Theory and Practice, was, in the most basic of terms, about literacy in Iran. Through an ethnographic approach, he studied the social construction of literacy, that context helped define what literacy is and how it was being used in complex ways. But while Street acknowledges his experience teaching in Mashhad and the "upheaval in the political order culminating in the fall of the Shah and the coming to power 
of Ayatollah Khomeini," he does not connect these contexts to how he conducts his research beyond these few sentences (129). Published in 1984, he doesn't share with us in the text about how he has entered the community in what he later identified as the village of Cheshmeh near the city of Mashhad (Street, Pishghadam, and Zeinali), nor his relationship with the people he is studying. But their voices and experiences are absolutely filtered through him. ${ }^{1}$ While he uses "I" in reference to his observations and interactions, the "I" is never interrogated. The closest Street comes to recognizing his own positionality as a researcher is when he describes a disagreement about whether he, as a Westerner, should be able to use a bathhouse, but that anecdote becomes more about how the situation was negotiated in terms of "rational argumentation" rather than his own status as researcher (148-152). The content of the research, that his goals to legitimize and understand the way literacy worked in Iran, a seemingly "illiterate" society, seemed to be revolutionary enough.

Yet in the years since, more scholars have used decolonial and anti-racist framings to ask what assumptions and ideologies a researcher might be bringing to a research project. The methodological expectations for critical ethnographic work have shifted, with ethnographic researchers needing to "acknowledge the privilege and power that come with assuming the Western academic's authoritative stance" (Alonso Bejarano, et al. 8). If I were to say, for instance, that Brian Street, a white scholar from Great Britain, did fieldwork in Iranian villages in the 1970s, our current day frameworks about antiracist and decolonial research methods might raise a few questions about this work. In Decolonizing Methodologies: Research and Indigenous Peoples, Linda Tuhiwai Smith describes the intrusion of outside researchers as "travellers' stories," noting how they were "generally the experiences and observations of white men whose interactions with indigenous 'societies' or 'peoples' were constructed around their own cultural views of gender and sexuality" (8). While Street's book is making explicit moves to resist this kind of research, to resist ethnocentric and autonomous understandings of literacy and instead understand how literacy works within a particular social context, rather than understood through a Western one, he also does not explicitly bring his own positionality into his research or consider how his positionality might affect the way he's understanding the literacy at work. As much as a researcher can attempt to construct the social contexts, if one is not part of that community, the effects of such a reading must be acknowledged and actively engaged with.

Does this mean that the work isn't good anymore? This is, in some ways, not the right question to ask because Street's study opened up multiple lines of literacy research that, in part, lead to the moment that we are in now. Street has influenced my own work, not just directly through his scholarship but also indirectly through other scholars he influenced who have, in turn, influenced me. But his sphere of influence is shaped by what kinds of knowledges have been deemed worthy within literacy studies and the academy more generally. And so I believe that alongside the foundational influences that Street has had on the field of literacy studies, these methodological and researcher positionality questions must also be acknowledged, as well as a recognition of how his knowledge was able to circulate in place of the knowledge of others.

I need to be clear about the scope of this article as well as its limits. I did not talk to Street before his passing in 2017 or to his collaborators. What I did do is look at his later work and his discussion of methodology to see if I could glean any insights into how he shaped his research over the course 
of his career, to construct historiographically out of the empty spaces, and to give meaning not just to what he wrote about but to who he wrote with. And my goal here is not to create an apologist's reconstruction of Street and his research, nor is it a cancellation of Street; rather I seek to find ways to move forward that acknowledge the significant impact he has had on literacy scholars with his arguments for understanding social constructions of literacy, while also recognizing the colonial context of how he conducted his research. Drawing from scholarship on decolonial and anti-racist methodologies, this piece is an attempt to focus on these methodological concerns by revisiting Street and by crafting a quasi-autoethnographic account of his influence on my own work to think through how we might continue to take up his research.

\section{Street: A Long View}

Like many in literacy studies, my first introduction to Brian Street was in a graduate seminar. At the University of Illinois at Urbana-Champaign, during my first year of graduate school in 2003, Cathy Prendergast assigned Literacy in Theory and Practice as part of her class on literacy, an eyeopening and far-reaching introduction to literacy studies. We worked our way through Street, Harvey Graff, Shirley Brice Heath, Deborah Brandt, and Eugene R Kintgen, Barry M. Kroll, and Mike Rose's Perspectives on Literacy, among others. In particular, we talked about the way Street's research acted as a kind of intervention against Great Divide scholarship and the importance of social values in the construction of literacy. Street became the touchstone for thinking about how literacy was embedded in social systems. What we did not seem to talk about, until we got to Heath later in the semester (or at least this is what my decades-old notes would have me believe), is the relationship between the studied communities and the researcher and the ways that a researcher decides what is seen. In "Race: The Absent Presence in Composition Studies," Prendergast describes the erasure of race in the field's scholarship and shows, through Heath and through Min-Zhan Lu's critique of Mina Shaughnessy's "formulation of students as strangers and foreigners," how "internalized colonial sensibilities might be congruent with a discussion of linguistic strategies" (47). She asks researchers and teachers to recognize the signals "where our colonizing impulses lie" (46). The recognition of these signals is crucial to understanding not just how your own positionality can get in the way, but also to understanding how your research design might account for it.

As part of the class, Cathy gave us the option for a semester project that had us tutoring within the local community and keeping a journal about our experiences and the connections we might be making with the literacy theories we were reading for class. Such an assignment set us up to start thinking about what it would be like to design a research project in community settings, allowing us to consider the concerns and contexts without inflicting a graduate student's clumsy first attempts at "research" onto a community group. I chose to tutor high school students at the local Urban League office as part of a broader effort to increase the low number of African American students graduating from city high schools. Students from town, often Black and Brown, came in because they were encouraged by teachers, guidance counselors, and other mentors. But more often than not, I spent tutoring time talking to my (white) friend and classmate who was also volunteering 
because students were not flooding in to be tutored.

As I look back at my tutoring field notes, unearthed from the bottom drawer of a file cabinet in my office, I remember the depressing tale of a program that was given funding at the last minute and seemed to flounder, with only a handful of students coming in for tutoring. I also read my own rudimentary observations about students' non-school literacy practices, the wondering about the factors, or sponsors, if I were to apply then new-ish work by Deborah Brandt, that were part of the story of how minoritized students got so close to the edge of not graduating. As I leafed through these old notes, I feared that I would come across a cringey or insensitive observation, one made before I "knew better," but I should have had more faith in myself. What I read is a young graduate student who is earnestly trying to make sense of this situation, wanting to "do something" but not sure how.

I questioned the structure of the program, the relationships between tutors and students, and, specifically, my own racialized and classed positionality as an Asian American graduate student who was not from the local community. This disconnect between my practice, as a graduate student who was trying to get an assignment done, and the community itself was stark. There was an understandable distance, but it was one I was not sure how to bridge. It's not that there was open hostility between the program and the students, at least from my perspective-the students simply didn't come. And the ones who did come did so sporadically. There was not meaningful co-learning going on, as much as that was my naive expectation. Whether students' actions were active resistance, dependent on some past history with the sponsoring organization, structural constraints, or something else-I'll never know because I didn't ask them, nor did my own rudimentary approach question the logic of the tutoring program itself, embedded in the histories, funding, spaces, and structures of the program or the educational system.

To ask such questions might have allowed for an approach that would acknowledge what Walter Mignolo calls pluriversality, "the name and the horizon of all decolonial trajectories today, on the planet, arising from the awareness of repressive forces of coloniality" (94). This term "names the visions of hundreds of thousands of organizations arising from the moment people realize they cannot expect much if anything from either the states or the corporations" (95). While he speaks specifically about pluriversality in relation to a delinking from global political society (what might traditionally be understood as social movements and resistance among the structures of the governments), what pluriversality describes is the equal recognition of the overlapping and multiple systems that people develop to sustain themselves, both resisting and working beyond frameworks of colonialism and the state. For researching literacy programs, like the tutoring program where I volunteered in graduate school, scholars like Ellen Cushman have advocated understanding "pluriversal contexts, values, and purposes for meaning making" as a way to incorporate how language and sign system hierarchies "index the social hierarchies implicit in, indeed necessary for, imperialism" (240). Such an approach, similar to Michael T. MacDonald's decolonial approaches to sponsorship in his research on an afterschool program for refugee youth, would give space to incorporate an analysis of a variety of power structures that include the researcher and acknowledge the possibilities for supporting students that already existed outside of the program itself, a way to understand the many potential systems that 
could be at work in a district with low graduation rates of Black students and recognize the likely limited possibility of a tutoring program to solve these issues with graduation rates.

Brian Street himself recognizes the dominance of certain systems and the erasure of others in chapter seven of Literacy in Theory and Practice about United Nations Educational, Scientific and Cultural Organization (UNESCO) literacy work when he questions concepts of "functional literacy" across UNESCO programs and the way the literacy promoted is born out of economic systems. Street argues that these programs operated without "any reference to the material and political conditions in which those particular 'functions' operated" (183), making these ideological definitions appear to be neutral (186). In ways that must have been eye-opening at the time, earning him the status of being a foundational scholar within literacy studies, he questions how UNESCO's programs and its developmentalists use stereotypes and "romantic primitivism" (189) to promote the need for functional literacy, making literacy programs a project of modernization and colonization. In this part of the book, he provides context for how these programs forward definitions of literacy that erase the literacies he describes earlier. While providing an astute critique of power being held in organizations like UNESCO and within broader economic systems, he shines a light on UNESCO workers' ideologies and how these ideologies might be cultivated and maintained. As in the argument about the social contexts of literacy, Street questioned deeply held assumptions about the benefits of such literacy programs. Yet, while Street's research works to uncover the stereotypes and ideologies of a dominant system of modernization and colonization that affect understandings of literacy and could be seen as doing decolonial work in one sense, he does not address his own role in these systems or explicitly ask questions about how these dominant systems and coloniality have influenced his own context as a researcher and his research practices within Western academic knowledge-making.

Conversations about methodology have become much more prominent since 1984, when Street's first book was published. In particular, scholarship about decolonial and anti-racist research methods has pushed an understanding of methods beyond a singular, narrow, and definable set of practices. Questions about this process of who is speaking, who is studying whom, as well as how and why, is a prominent strain of methodological inquiry in literacy studies, writing studies, and composition and rhetoric (Agboka; Gilyard; King, Gubele, and Anderson.; Martinez; Powell; Royster; Vieira, to name just a few). This isn't to say that these questions were not concerns among academics in 1984. Postcolonial scholar Edward Said's Orientalism, a foundational text in its own right that examined how the East was shaped by the Western gaze and representation, was published in 1978, six years before Street's first book, while he was doing his fieldwork; it seems fair to acknowledge the ways that Street's work could be seen as orientalist. ${ }^{2}$ In the introduction to their collection, Rhetorics Elsewhere and Otherwise: Contested Modernities, Decolonial Visions (2019), Romeo García and Damián Baca track how postcolonial and decolonial scholars have addressed what it means to study other people and cultures since Said, describing the necessity of changing "the terms as well as the contents of knowledge production, thus changing the epistemes in which politics occurs" (15). This shift in thinking about the terms of knowledge production asks the researcher to consider and make explicit how they might shape or be implicated in the terms that already exist and how dominant colonial ideologies continue to frame the research being done. 
Street would agree with this point. In an interview with Street and Harvey Graff, published in LiCS in 2014, Street describes "an ethnographic perspective as being epistemological recognition of how we understand images of local people's meanings and practices. We apply that to literacy then, and so you say to policy makers and people in school contexts 'ok, let's find out what people themselves make of reading and writing"' (de Oliveira Galvão, et al. 56). In terms of the consequences of his kind of approach to literacy studies, he explains that "we go back to square one to ask who said the word 'literacy.' You have to say 'what do you mean by it,' not assume we'll know where we're going. And that's just the word literacy. Start doing that with other words, like class, gender, ethnicity...." (de Oliveira Galvão, et al. 61). While this is not necessarily evident in his early work, Street does seem to recognize the importance of these factors and how his own positionality influences the contexts of interpretation in the later part of his career.

In some of Street's later work, he looks at his most immediate community-that of higher education, to turn his analytical lens toward the cultural context in which he had the most knowledge and where autonomous models of literacy are still built. His writing on institutions of higher education shows how he focused his valuable critical lens on the space that he inhabited most directly. In "Revisiting the Question of Transformation in Academic Literacies: The Ethnographic Imperative," he talks about how "an ethnographic perspective forces you to suspend your own assumptions as to what counts as literacy and to listen to and observe what people are actually doing" (384) and "that was the basis for looking inside our own systems, in universities and saying let's apply these ideas here" (384). And I think that this move is a good reminder to all of us who work in literacy and in university spaces, that our knowledge and frameworks can be most useful in our everyday contexts and that our insights, as literacy researchers, can be used to influence the policies and the structures that surround the way literacy is being used in relation to our students every day in our institutions.

In reading Street's last published article from 2016, "Learning to Read from a Social Practice View: Ethnography, Schooling and Adult Learning," I was struck by his discussion about the autonomous model as the still dominant way of understanding literacy, particularly in educational contexts. But, of course, he's right. While those of us in literacy studies might see the argument about autonomous versus ideological approaches to literacy as quaint, we see this logic still at work most discussions about schooling and literacy, such as in the model immigration rationales that require DACA recipients to be high school graduates, GED earners or veterans to justify their staying in the country, as if school success were somehow going to make someone more valuable than others; and the way that literacy is being conflated or combined with economic success and personal value. So many of our policies enact this logic.

For instance, in my own current research project, I study rhetorics of global citizenship and the global university in relation to policies that use literacy as a measurement of belonging for minoritized multilingual students. The judgments about the readiness, language abilities, and sense of belonging of international and multilingual students, the ways they are determined to be literate in the context of higher education, contradicts the larger discourses about diversity and global citizenship that intend to create access to institutions of higher education. Universities love to tout the production of global citizenship among their students, yet their policies and practices often exclude those who 
are already "global," placing students into different categories that marginalize them from the general student population.

In emails that went viral in January 2019, the Director of Graduate Studies (DGS) of a master's program in biostatistics at Duke University asked Chinese international students to stop speaking Chinese in the common areas of the building, saying that professors were judging this choice and that future research and internships might be affected by that judgment (Blum). In Social Literacies: Critical Approaches to Literacy in Development, Ethnography and Education, Street writes, "[W]e are particularly concerned with the processes that help construct an 'autonomous' model of literacy-in which many individuals, often against their own experience, come to conceptualize literacy as a separate, reified set of 'neutral' competencies" (114) and describes how

[p]rocedures for organizing classroom time, work practices, and literacy materials dominate the classroom and form a major part of the pedagogic voice. One teacher told her students explicitly that they had to speak differently in class: 'Now you are in school, use your inside school voice. Thereby school is separated from other times and places, and familiar everyday processes of speaking, reading and writing are given a distinct character and a special authority. (121)

Street was talking about K-12, but there are obviously similarities with the Duke situation and in US higher education more generally, where multilingual students are invited in but the atmosphere becomes hostile because of their language use.

The logic of a situation like this becomes complicated when an institution is trying to acculturate people to a particular educational situation, a kind of assimilation model of transnational writing in which US classrooms are seen as the norm. But if we understand that US universities are truly supposed to be establishing themselves as global universities/spaces, then there's a contradiction here that needs to be investigated. And not just a contradiction as an object of study but as an active participant in these structures, ones to which we bring our own positionalities and ideologies and also knowledge. As the gatekeepers of literacies on our campuses, we need to recognize our own power and role in this process. As with the social contexts we bring to our research, we must also be vigilant about how our potentially colonial practices inhabit the classrooms we teach, the programs we administer, and the institutions who employ us.

In "At Last: Recent Applications of New Literacy Studies in Educational Contexts," from 2005, Street pointedly asks about the power relationship among participants in any kind of literacy program, connecting that power relationship to resources, different ways of defining literacy, and how students can challenge dominant conceptions. And he connects those questions that we as scholars ask about literacy to our practices and to the policies we make and enforce when he says, "Academics have, however, often failed to make explicit the implications of such theory for practical work. In the present conditions of world change, such ivory-tower distancing is no longer legitimate" (419). Street reminds us that literacy often gets reduced to mechanistic skills and that curricula and assessments need to be rich and complex (420). As literacy educators who want to acknowledge and build upon the "richness and complexity of learners' prior knowledge," we are asked by Street to "treat 'home background' not as a deficit but as affecting deep levels of identity and epistemology, and thereby the 
stance that learners take with respect to the 'new' literacy practices of the educational setting" (420). And in a conversation with Mary R. Lea and Theresa Lillis, Street talks about how "[n]one of this can be decoupled from institutional decision making about where and how to locate work around writing and the values and beliefs which underpin this" ("Revisiting" 388).

Street's later career work on universities and literacy reminds us about the continued importance of understanding larger contexts in which literacy is being used and judgments about literacy are being made. In higher educational, this can often mean practices and histories that lay in the policies that shape individual classroom spaces to the writing programs we might administer to university and national policies to the everyday practices of administrators like the Director of Graduate Studies at Duke. As a result, there is urgency in bringing our knowledge about literacy practices-that higher education and the literacy it cultivates has its own colonial contexts-and recognizing the influence of our positionalities to the practices and policies at our own institutions. In many ways, the people who make the institutional decisions are us. Is Street crucial to this work? Perhaps not. And perhaps the question isn't how do we move with Street but rather, how does he move with us?

\section{Changing the Terms of Foundational Research}

I didn't know Professor Street personally, so perhaps he or others who knew him would contradict what I'm about to say. But I think, either purposefully or not, his later work reflects a kind of evolution for dominant figures doing research in what Western academia would call marginalized communities. Rather than be a sole researcher who sought out groups that are traditionally "othered" by mainstream academia to show the ways that literacy was at work in those spaces, he instead collaborated with others and amplified voices. For instance, in his revisiting of Iran in 2013, he worked with Reza Pishghadam, who is a faculty member at Ferdowski University in Mashhad, although their shared work doesn't explicitly take up decolonial questions about researcher positionality or a move toward critical ethnography. In "Changes and Challenges of Literacy Practices: A Case of a Village in Iran," their article with Shiva Zeinaili, the discussion of methods and researchers' roles, while characterized as "open" and "led by what participants mentioned," still constructs an objective sense of the researchers and their analysis and does so without any reference to researcher positionality (20).

But these kinds of collaborations with other scholars and the number of book review essays that Professor Street wrote in the later part of his career represent his continuous engagement with other scholars and younger scholars. He made an effort to avoid privileging solely his own voice. These reviews, collaborations, and edited collections also demonstrate to me that it was important to him to engage with new voices and recognize that he had the power to amplify them, as well as show how new scholarship could help him rethink his own ideas, even when he was long into a very successful career.

The contradiction of Street comes from his efforts to do humanizing research that questions ethnocentric and colonial definitions of literacy within the colonial context of Western-dominant academia. Perhaps having an outsider like Street try to humanize, make meaning, and communicate 
those contexts on behalf of the people he's studying was a radical step in his particular moment, but as scholars right now, we have to acknowledge that such an approach, without critical reflection of who gets to do the humanizing and meaning making, is thorny. This doesn't necessarily mean an erasure of foundational scholarship like his but rather a recognition of the other stories that were happening at the time, that the people who are described in his book might be interpreting these moments in a different way, that their voices could be more present, and that despite the efforts to do otherwise, the definitions and understandings of literacy within a higher educational context, of the colonizers and the colonized, are still seeping in. Even in Street's goal to show the meaning of literacy in social contexts, the meanings are still filtered through him.

In The Extractive Zone, Macarena Gómez-Barris describes the importance of looking for "submerged perspectives" that "pierce through the entanglements of power to differently organize the meanings of social and political life" (11, emphasis in original). She argues that a decolonial approach must "rais[e] the submerged perspectives" and study the multiple in order to "decenter a singular eye" (12). For Gómez-Barris, this means a "queer decolonial femme method [that] recognizes a plurality of meaning systems, interpretations, and selections to reconsider what we thought we had known by challenging its disciplinary foundation" (11). She argues for the need to study and make space for the "multiplicity that is submerged perspectives" (12). It is in this multiplicity where researchers must reckon with their foundational scholars.

The content of Street's research was groundbreaking within the context of academic literacy studies, but that tension about his methodology still exists. The expectation to address researcher positionality and to give space to the voices of those who are the objects of study helps make clear how the researcher and their own ideological assumptions might be informing the analysis. Even when researcher positionality is not part of the conversation, there should be more clarity about who is being asked and how, as a way for readers to be able to draw their own conclusions about what brought this information to the page and what might have influenced it along the way.

And with the growing awareness of citation politics (Ahmed; Delgado; Mott and Cockayne; Ray; Wallis), the practice of thinking about the ways that one's citations reflect the dominance of gender and race in the way knowledge gets made, there is a growing expectation for a more critical approach to who we cite as literacy scholars. As Kynard argues in Vernacular Insurrections: Race, Black Protest, and the New Century in Composition-Literacy Studies, a history of literacy's contexts and literacy as a social practice can be drawn, for instance, from grassroots Black-centered education and arts movements. But that branch of literacy scholarship isn't necessarily seen to be as much a part of the New Literacy Studies world as is Street. ${ }^{3}$

So much of what Street is doing is demonstrating modernity and literacy in a culture that was othered and exoticized, but the more traditional social science writing genres that he often adheres to mean that he doesn't explicitly acknowledge the ways his positionality also plays a role, even when he is making that critique of others. The context of white Western researcher; of British colonial relationships with Iran (including the oil wars of the 1970s); of the whiteness of academic discourse; of the objectifying, exoticizing and Orientalizing of non-European spaces is also all part of this story, even when or perhaps because Street's critiques and arguments captures much of this in how literacy 
in these spaces should be understood through local contexts. Yet his analysis is still absent of his own positionality as a researcher. And all of these things can be true concurrently, which illustrates the complexity of this work, of building on knowledge in these multiple ways. And so rather than reconciling these seemingly unresolvable positions, what we can do as researchers is develop a kind of recognition of the way these multiple interpretations are at work (Martinez; Watson and Huntington). To that end, it's important to do the work in terms of our own research design, and this includes considering what is missing and why that's the case, creating spaces and opportunities to amplify voices. Additionally, we must consider the ways that our own concepts and research frames are emerging from colonial contexts (MacDonald).

The asterisk that we individually put on Street's work because of its history and how it was conducted is a choice we must make as researchers, and these are important considerations when thinking about citations and the way that literacy researchers situate foundational work in general. What were the circumstances under which this research was conducted? What were the terms? And how were these contexts created out of colonial, political, and institutional situations? The relationship between Great Britain and Iran that was rife with colonialism and oil, the colonial impulses of anthropology and knowledge making in higher education-these are all factors to consider when considering what brings a researcher to that space. Street's situated and localized qualitative research in Iran was groundbreaking in literacy studies within that context of a Western academic recognizing Iranian people and literacy within communities as having value in its own right, yet it doesn't mean that we can't still question where the "submerged perspectives" are.

I asked earlier how we can move forward with Street, and I want to acknowledge that some of us can't, that being able to hold him as foundational is a kind of privilege and that I, of course, am speaking from my own privilege and positionalities and am waiting and wanting to hear from others. What we can do, as a scholarly community, is commit to making space for these questions about methodology as part of our continuing conversation, to create opportunities for those who can say that this foundational work did harm, to be answerable to and recognize one another, to revisit foundational research-to build on it or to tear it down or to be clear about how these stories were told and why we have listened to them-and this is how we need to carry on. 


\section{NOTES}

${ }^{1}$ In Decolonizing Ethnography: Undocumented Immigrants and New Directions in Social Science, Alonso Bejarano, Juárez, García, and Goldstein describe how early anthropology was born out of the "broader Enlightenment project of discovering the unknown" with early anthropologists studying "the peoples of the lands then colonized by Europe and the United States" (2). The result was an anthropology that acted as a science. And while Street's arguments about the importance of social context moves away from this dominant "colonial anthropology" (3), he does not explicitly argue against it.

2 Jordan Clarke Hayes raises a similar question in his dissertation, Trajectories of Belonging: Literacies and Intersectionality in the Mobile Phone and Home Building Practices of Syrian Refugees in the Kurdistan Region of Iraq (30-34).

${ }^{3}$ Anna Zeemont made this point during the course of her orals exam at the CUNY Graduate Center on January 25, 2020. 


\section{WORKS CITED}

Agboka, Godwin Y. "Decolonial Methodologies: Social Justice Perspectives in Intercultural Technical Communication Research.” Journal of Technical Writing and Communication, vol. 44, no. 3, 2014, pp. 297-327.

Ahmed, Sara. On Being Included: Racism and Diversity in Institutional Life. Duke UP, 2012.

Alonso Bejarano, Carolina, Lucia López Juárez, Mirian A. Mijangos García, and Daniel M.

Goldstein. Decolonizing Ethnography: Undocumented Immigrants and New Directions in Social Science. Duke UP, 2019.

Blum, Susan D. "Speak Softly . . o or at Least Speak English.” Inside Higher Ed, 30 Jan. 2019, www. insidehighered.com/views/2019/01/30/academe-should-not-police-international-studentsspeech-opinion. Accessed 30 Jan. 2019.

Brandt, Deborah. Literacy in American Lives. Cambridge UP, 2001.

Cedillo, Christina V. "What Does It Mean To Move?: Race, Disability, and Critical Embodiment Pedagogy." Composition Forum, vol. 39, 2018, compositionforum.com/issue/39/to-move.php. Accessed 3 June 2020.

Cushman, Ellen. “Translingual and Decolonial Approaches to Meaning Making.” Translingual Work in Composition, special issue of College English, vol. 78, no. 3, 2016, pp. 234-42. de Oliveira Galvão, Ana Maria, Maria Cristina Soares de Gouvêa, and Ana Maria Rabelo Gomes. "An Interview with Harvey J. Graff and Brian Street." Literacy in Composition Studies, vol. 5, no. 1, 2017, pp. 49-66, https://licsjournal.org/index.php/LiCS/article/view/751. Originally published as "Interview with H. Graff \& B. Street" in Educação em Revista, April/June 2016. Accessed 3 Dec. 2019.

Delgado, Richard. “The Imperial Scholar Revisited: How to Marginalize Outsider Writing, Ten Years Later." University of Pennsylvania Law Review, vol. 140, no. 4, 1992, pp. 1349-372.

García, Romeo, and Baca, Damián, editors. Rhetorics Elsewhere and Otherwise: Contested Modernities, Decolonial Visions. NCTE, 2019.

Gilyard, Keith. "African American Contributions to Composition Studies." College Composition and Communication, vol. 50, no. 4, 1999, pp. 626-44.

Gómez-Barris, Macarena. The Extractive Zone: Social Ecologies and Decolonial Perspectives. Duke UP, 2017.

Harrison, Faye V., editor. Decolonizing Anthropology: Moving Further toward an Anthropology for Liberation. $3^{\text {rd }}$ ed., American Anthropological Association, 2010.

Hayes, Jordan Clarke. Trajectories of Belonging: Literacies and Intersectionality in the Mobile Phone and Home Building Practices of Syrian Refugees in the Kurdistan Region of Iraq. 2020. University of Pittsburgh, PhD dissertation.

Inoue, Asao B. "Racial Methodologies for Composition Studies: Reflecting on Theories of Race in Writing Assessment Research.” Writing Studies Research in Practice: Methods and Methodologies, edited by Lee Nickoson and Mary P. Sheridan, Southern Illinois UP, 2012, pp. 125-39. 
King, Lisa, Rose Gubele, and Joyce Rain Anderson, editors. Survivance, Sovereignty, and Story: Teaching American Indian Rhetorics. Utah State UP, 2015.

Kovach, Margaret. Indigenous Methodologies: Characteristics, Conversations, and Contexts. U of Toronto P, 2009.

Kynard, Carmen. "Literacy/Literacies Studies and the Still-Dominant White Center." Literacy in Composition Studies, vol. 1, no. 1, 2013, pp. 63-65, https:/licsjournal.org/index.php/LiCS/ article/view/805/629. Accessed 5 Dec. 2019.

---. Vernacular Insurrections: Race, Black Protest, and the New Century in Composition-Literacy Studies. SUNY P, 2013.

MacDonald, Michael T. “My Little English': A Case Study of Decolonial Perspectives on Discourse in an After-School Program for Refugee Youth." Community Literacy Journal, vol. 11, no. 2, 2017, pp. 16-29.

Martinez, Aja Y. "A Plea for Critical Race Theory Counterstory: Stock Story versus Counterstory Dialogues Concerning Alejandra's 'Fit' in the Academy.' Composition Studies, vol. 42, no. 2, 2014, pp. 33-55.

Mignolo, Walter D. "On Pluriversality and Multipolar World Order: Decoloniality after Decolonization; Dewesternization after the Cold War." Constructing the Pluriverse: The Geopolitics of Knowledge, edited by Bernd Reiter, Duke UP, 2018, pp. 90-116.

Mott, Carrie, and Daniel Cockayne. "Citation Matters: Mobilizing the Politics of Citation Toward a Practice of 'Conscientious Engagement." Gender, Place \& Culture: A Journal of Feminist Geography, vol. 24, no. 7, 2017, pp. 954-73.

Mutua, Kagendo, and Beth Blue Swadener, editors. Decolonizing Research in Cross-Cultural Contexts: Critical Personal Narratives, SUNY P, 2004.

Patel, Lisa (Leigh). "Countering Coloniality in Educational Research: From Ownership to Answerability." Educational Studies, vol. 50, no. 4, 2014, pp. 357-77.

Powell, Malea. "2012 CCCC Chair's Address: Stories Take Place: A Performance in One Act.” College Composition and Communication, vol. 64, no. 2, 2012, pp. 383-406.

Prendergast, Catherine. "Race: The Absent Presence in Composition Studies." College Composition and Communication, vol. 50, no. 1, 1998, pp. 36-53.

Ray, Victor. “The Racial Politics of Citation.” Inside Higher Ed, 27 Apr. 2018, www.insidehighered. com/advice/2018/04/27/racial-exclusions-scholarly-citations-opinion. Accessed 15 July 2020.

Royster, Jacqueline Jones. "When the First Voice You Hear Is Not Your Own." College Composition and Communication, vol. 47, no. 1, 1996, pp. 29-40.

Said, Edward. Orientalism. Pantheon, 1978.

Sefa Dei, George J. "Chapter One: Critical Issues in Anti-racist Research Methodologies, An Introduction." Counterpoints, vol. 252, 2005, pp 1-27.

Smith, Linda Tuhiwai. Decolonizing Methodologies: Research and Indigenous Peoples. Zed Books, 1999.

Street, Brian V. "At Last: Recent Applications of New Literacy Studies in Educational Contexts." Research in the Teaching of English, vol. 39, no. 4, 2005, pp. 417-23. 
---. "Learning to Read from a Social Practice View: Ethnography, Schooling and Adult Learning," Prospects, vol. 46, no. 3/4, 2016, pp. 335-44.

---. Literacy in Theory and Practice. Cambridge UP, 1984.

---. Social Literacies: Critical Approaches to Literacy in Development, Ethnography and Education. Routledge, 1995.

Street, Brian V., Reza Pishghadam, and Shiva Zeinali. "Changes and Challenges of Literacy Practices: A Case of a Village in Iran." International Journal of Society, Culture, and Language, vol. 3, no. 1, 2014, pp. 16-27.

Street, Brian V., in conversation with Mary R. Lea and Theresa Lillis. "Revisiting the Question of Transformation in Academic Literacies: The Ethnographic Imperative." Working with Academic Literacies: Case Studies Towards Transformative Practice, edited by Theresa Lillis, Kathy Harington, Mary R. Lea, and Sally Mitchell, WAC Clearinghouse; Parlor P, 2015, pp 383-90.

Vieira, Kate. "Writing about Others Writing: Some Field Notes." Rhetorics Elsewhere and Otherwise: Contested Modernities, Decolonial Visions, edited by Romeo García and Damián Baca, NCTE, 2019, pp. 49-61.

Wallis, Lauren. "Mapping Power and Privilege in Scholarly Conversations" Critical Library Pedagogy Handbook, edited by Nicole Pagowsky and Kelly McElroy, vol. 2, ACRL, 2016, pp. $1-7$.

Watson, Annette, and Orville H. Huntington. "They're Here-I Can Feel them: The Epistemic Spaces of Indigenous and Western Knowledges." Social \& Cultural Geography, vol. 9, no. 3, 2008, pp. 257-81.

Weis, Lois, and Michelle Fine. "Critical Bifocality and Circuits of Privilege: Expanding Critical Ethnographic Theory and Design." Harvard Educational Review, vol. 82, no. 2, 2012, pp. 173201.

Wilson, Shawn. Research is Ceremony: Indigenous Research Methods. Fernwood Publishing, 2008. 